UNIVERSIDADE DE BRASÍLIA - UNB

INSTITUTO DE CIÊNCIAS HUMANAS - IH

DEPARTAMENTO DE GEOGRAFIA- GEA

MOBILIDADE PENDULAR ENQUANTO NOVA ORDEM ESPACIAL NO DISTRITO FEDERAL 


\section{ALEX SOUZA DA COSTA}

\section{MOBILIDADE PENDULAR ENQUANTO NOVA ORDEM ESPACIAL NO DISTRITO FEDERAL}

Monografia como requisito para a obtenção do título de Bacharel e

Licenciatura em Geografia - Departamento de Geografia da Universidade de Brasília.

Professora orientadora : Dra Marília Peluso

Brasília/DF

01 de julho de 2009 


\title{
MOBILIDADE PENDULAR ENQUANTO NOVA ORDEM ESPACIAL NO DISTRITO FEDERAL
}

\author{
ALUNO: ALEX SOUZA DA COSTA
}

Monografia como requisito para a obtenção do título de Bacharel e Licenciatura em Geografia, submetida à Banca examinadora em 01 de julho de 2009, formada por:

\section{BANCA EXAMINADORA:}

\author{
Professora orientadora Dra Marília Peluso \\ Presidente
}

\author{
Professor Ms Juvair Fernandes de Freitas \\ Convidado
}
Professor Ms Gilberto Oliveira Júnior Convidado




\section{AGRADECIMENTOS}

"Deus", todo poderoso, obrigado por esta oportunidade e através dos seus desígnios, utilizou seus filhos, instrumentos em vossas mãos, para que esse objetivo fosse alcançado.

Agradeço a minha mãe querida, senhora Neusa Maria, por todos os esforços realizados durante a sua vida, para proporcionar aos seus filhos uma melhor educação. Essa vitória, também, pertence a ela.

A minha esposa Natália que em todos os momentos difíceis, esteve sempre pronta, incentivando e motivando, participando de cada situação por mim, vencida, para poder alcançar este momento de glória.

Ao companheiro de profissão e graduação Nilton, que com toda camaradagem e disponibilidade me ajudou na construção desse trabalho de monografia e que nós sejamos iluminados ao transmitir tão vastos conhecimentos no decorrer de nossas vidas, seja em qualquer situação.

A professora orientadora Marília Peluso, muito obrigado, mesmo com todos os seus compromissos, prontificou-se a conduzir-me no final desta jornada que continue transmitindo seus conhecimentos com maestria e generosidade, sendo mola mestra no conceito de ensino de nosso departamento e instituição.

A todos os colegas que durante esses anos se empenharam e se comprometeram com a conclusão da graduação e gradativamente construímos uma amizade e que todos, de agora em diante, possam alcançar novos objetivos. 


\section{RESUMO}

A mobilidade pendular é o conjunto de deslocamentos que o cidadão realiza para executar os atos de sua vida cotidiana, é um fenômeno que continua atualíssimo, envolvendo todas as classes sociais, tendo um significado diferenciado para cada uma delas, oferecendo ou não mais, flexibilidade, conforto, agilidade, um aproveitamento melhor do tempo, que cada cidadão utiliza, essas ações colaboram com as mudanças da cidade em vários sentidos, modificando o espaço e a paisagem em que nós estamos representados.

Brasília é constituída do Plano Piloto e suas Regiões Administrativas e a integração da população local e mais os seus diversos imigrantes, todos esses elementos compõem a estrutura orgânica e inorgânica de nossa cidade e suas perspectivas em relação ao cotidiano, suas dificuldades e as expectativas de crescimento que cada elemento desse núcleo almeja, porém não devemos esquecer que a busca pela estabilidade através do dinheiro confere às grandes cidades suas duas características mais marcantes que é o intelectualismo e a calculabilidade, e do outro a indiferença.

O primeiro capítulo descreve o nascimento da cidade de Brasília, suas formas, conteúdo, como sua população surge, interage e contribui para evolução desse meio. No segundo capítulo será mostrado a importância da construção da UnB para a população local e nacional o que representa para o crescimento intelectual daqueles que a utilizam. No capítulo III é descrito a necessidade do transporte coletivo para a população de Brasília-DF, uma necessidade que envolve toda a nação brasileira e retornando para nossa cidade pesquisaremos os alunos da Universidade de Brasília e sua problemática.

O capítulo IV é um breve histórico do surgimento do ensino universitário no mundo, oportunizando a melhoria e qualificando-o para todos os que buscam essa oportunidade. No último capítulo é apresentado o resultado das entrevistas realizadas com amostras de vinte e cinco alunos da UnB, objetivando identificar seus problemas e quais as motivações que os conduzem diante das adversidades. Concluímos ratificando as construções dos novos campus universitário que proporciona ao povo brasiliense mais oportunidade de ingressar no curso superior gratuito e com qualidade, a flexibilidade desse deslocamento que otimiza e motiva mais esses universitários minimizando seus custos com passagens, a necessidade da participação da administração da UnB em fornecer melhores 
condições para o deslocamento interno de todos aqueles que frequentam o campus da universidade. A participação do GDF na discussão com a classe estudantil para a viabilização do passe livre, transporte coletivo com mais qualidade e segurança, e uma mudança necessária na malha viária local, beneficiando o deslocamento de todos os usuários.

A credibilidade nacional que a instituição conquistou, deverá proporcionar um melhor diálogo com os atores que decidem a vida daqueles que utilizam a UnB e cabe a cada um de nós a participação efetiva, colaborando intensamente para o processo de mudança nos assuntos que nos são atinentes.

Palavras - chave: Mobilidade pendular, transporte coletivo, universitários e urbanização. 


\section{LISTA DE FIGURAS}

FIGURA 1 - Distribuição de Curso...........................................................................29

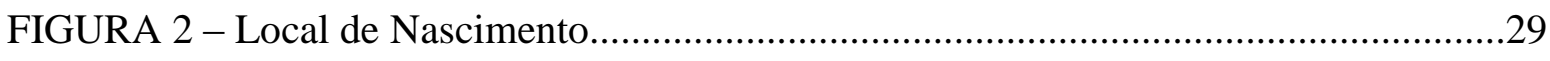

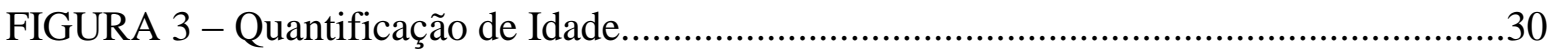

FIGURA 4 - Tempo Gasto no Deslocamento............................................................. 31

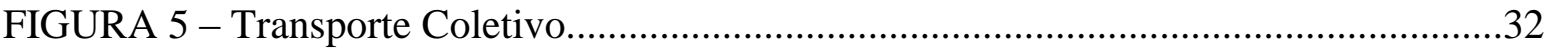

FIGURA 6 - Gasto com Passagem Valor Integral..........................................................33

FIGURA 7 - Gastos com Cartão de Passagem Escolar....................................................33 


\section{LISTA DE SIGLAS}

UnB Universidade de Brasília

DF Distrito Federal

SLP Secretaria de Planejamento da UnB

CO Centro Olímpico

BCE Biblioteca Central da Unb

RAs Regiões Administrativas

GDF Governo Distrito Federal

TCB Transporte Coletivo de Brasília

DFTrans Transporte Urbano do Distrito Federal 


\section{SUMÁRIO}

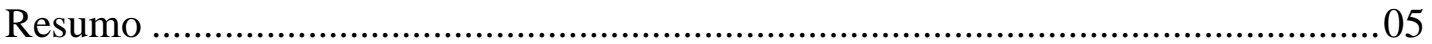

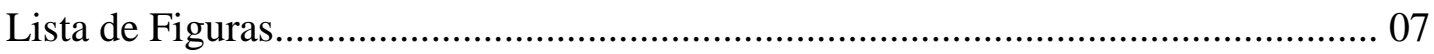

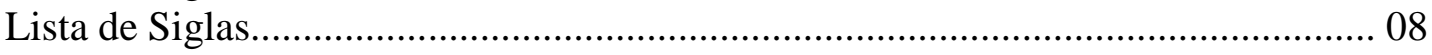

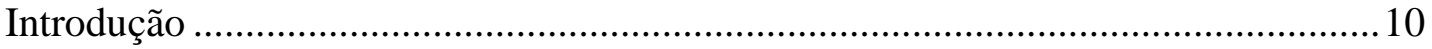

\section{CAPÍTULO 1}

1. O surgimento e características da cidade de Brasília.........................................14

2. Aspectos de expansão do aglomerado de Brasília............................................. 17

\section{CAPÍTULO 2}

1. História da Universidade de Brasília.

\section{CAPÍTULO 3}

1. Transporte coletivo.

\section{CAPITULO 4}

1. A universidade no mundo e o seu crescimento.

\section{CAPITULO 5}

1. Educação e Prosperidade.

\section{CAPITULO 6}

Considerações Finais.

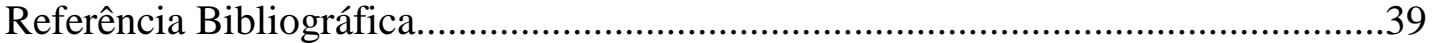

Apêndice A - Entrevistas da Pesquisa............................................................... 41

Apêndice B - Tabela com os resultados das Entrevistas............................................42

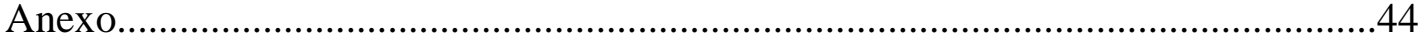




\section{INTRODUÇÃO}

A mobilidade pendular consiste no deslocamento de uma pessoa entre seu local de residência e uma atividade diária, também considerada como ordem circulatória. É um fenômeno que merece atenção por parte dos pesquisadores, considerando que os indivíduos vivem cotidianamente se deslocando nas suas diversas atividades para executar os compromissos sociais que impulsionam esse deslocamento contínuo, que não para dia e noite, exigindo da população brasileira, desenvoltura para encarar o cansaço físico e metal, o stress psicológico e o desafio em gastos com transporte coletivo. Neste contexto específico, analisaremos a trajetória dos estudantes universitários brasilienses, particularmente os alunos da UnB, por estarem inseridos ativamente neste objetivo, que é concluir o curso superior, dentre outras questões. ${ }^{1}$

Dentre alguns aspectos da geografia moderna, como os sociais e ambientais, contamos com pressupostos da mobilidade intra-urbana, que no geral reflete as disparidades da qualidade de vida entre algumas regiões administrativas e que denota a separação dos locais de trabalhos, de residências e de estudos, próprio do momento atual.

Segundo Milton Santos ${ }^{2}$, a globalização faz também redescobrir a corporeidade. O mundo da fluidez, a vertigem da velocidade, a freqüência dos deslocamentos e a banalidade do movimento e das alusões a lugares e a coisas distantes, revelam, por contraste, no ser humano, o corpo como uma certeza materialmente sensível, diante de um universo difícil de aprender (2004, p. 313 e 314).

A compreensão de um dos fenômenos da mobilidade social, que neste caso diz respeito aos deslocamentos pendulares, se torna pertinente, considerando a visibilidade e expressividade do entendimento deste fenômeno social, que envolve um conjunto de categorias analíticas internas, como paisagem, a configuração territorial, a divisão territorial do trabalho, o espaço produzido ou produtivo, as rugosidades e as formas-conteúdo que interferem, também, no cotidiano dos frequentadores da UnB, que se notabilizam como um fluxo populacional, em busca de conhecimento nas diversas áreas de ensino.

Por estas razões, além de pertinente, a temática do deslocamento pendular busca contribuir com a compreensão deste tipo de deslocamento, que traz contidas inúmeras

ANTICO, Cláudia. Deslocamentos pendulares nos espaços Sub-regionais da Região Metropolitana de São Paulo. Trabalho apresentado no XIV Encontro Nacional de Estudos Populacionais, ABEP, realizado em Caxambu - MG - Brasil, de 20 a 24 de setembro de 2004.

2 SANTOS, Milton. A Natureza do Espaço: Técnica e Tempo, Razão e Emoção. - $4^{\mathrm{a}}$ ed. Editora Edusp, 2004. 
implicações, para além de um entendimento superficial, de achar que deslocamento se encerra como movimentos naturais do seu habitat/ trabalho/universidade/habitat.

Deslocamento pendular representa uma ordem circulatória metropolitana, que traz consigo o grau de integração entre as pessoas e um determinado espaço ou lugar. A pesquisa realizada pontuará quais os fatores que mobilizam certo número de estudantes de sua casa/trabalho/Universidade de Brasília/casa, posto que o tempo é um fator de destaque neste processo, além do desgaste metal, físico e a projeção orçamentária nos gastos da família para concretização de uma determinada graduação.

Enquanto deslocamento funcional, este tipo de estudo exige o entendimento de uma frequência cotidiana de pessoas, sendo que cada uma tem sua singuralidade (particularidades), e são atravessadas por uma ordem circulatória, cuja norma de intinerância pressupõe a dimensão geográfica do espaço onde mora e estuda como também do espaço onde trabalha e estuda. Isto implica na necessidade de saber quais os procedimentos usados para concretização do curso superior por esses universitários que foram entrevistados, já que eles representam uma parcela que realizam os fluxos pendulares entre um espaço e outro, enquanto dinâmica espacial, com o intuito de garantir a sua posição em seus futuros postos de trabalho, e ascender intelectualmente ${ }^{3}$. Identificar as precariedades dos meios de transportes locais que dificultam e interferem no deslocamento desses estudantes é um tema que também será abordado.

Nesta perspectiva, foi pesquisado elementos que contribuam para a explicação dos deslocamentos pendulares, enquanto mobilidade individual para adaptação ao meio, considerando a expansão do aglomerado de Brasília.

O procedimento metodológico desenvolvido nesta monografia, diz respeito aos parâmetros da geografia humana ${ }^{4}$ utilizando o espaço, paisagens e lugares que propiciam vivências e experiências para cada pessoa, e, concorrentemente, para grupos de indivíduos que acabam por estabelecer uma interdependência com a sua "geograficidade".

Para a realização desta pesquisa foi utilizado um roteiro de entrevista clínica não estruturada, aplicada em uma amostra aleatória de vinte e cinco alunos, distribuídas em diversos cursos. Foi realizada uma abordagem do ponto de vista de cada um, sobre esse movimento pendular que interfere intimamente na vida desse cidadão, ou seja, como 
contornar essas dificuldades e dar prosseguimento na conclusão do curso superior, numa instituição tão renomada como a Universidade de Brasília. Portanto, procurou-se entender como enfrentar essas dificuldades e como superá-las, com a certeza que no decorrer desta caminhada os possíveis problemas serão contornados. Em função disso, a metodologia é qualitativa e implicou no emprego da modalidade de entrevista clínica, a qual permite estudar os motivos, os sentimentos, a conduta das pessoas em relação a um determinado fenômeno, que neste caso se refere à mobilidade pendular.

Por se tratar de entrevista do tipo não-estruturada, o entrevistador tem liberdade para desenvolver e explorar uma determinada questão, em geral, com perguntas abertas e respondidas de maneira informal.

A pesquisa bibliográfica foi valorizada com a finalidade de verificar o que já havia sido escrito sobre mobilidade pendular, formando uma base teórica que desse suporte para analisar os motivos que influenciam esses universitários a se deslocarem internamente no espaço urbano. A divisão desta monografia inicia-se com uma explanação sobre o caráter interdisciplinar do tema, definindo o surgimento e características do Aglomerado Urbano de Brasília, expondo os objetivos específicos que permitiram analisar os motivos que levam as pessoas a realizarem a mobilidade pendular e a importância da utilização do transporte coletivo neste contexto.

Este trabalho foi dividido em cinco capítulos, sendo que no primeiro é analisado o surgimento e as características da cidade de Brasília, através de dois conceitos que são de fundamental importância para se entender à cidade como fenômeno a partir da relação entre uma cidade orgânica e uma cidade inorgânica. Os conceitos de urbs e civitas são importantes instrumentos teóricos para esse entendimento. Com o surgimento da UnB, engrandecendo as novas estruturas da cidade de Brasília e oferecendo oportunidade de ensino gratuito, se tornando referência de qualidade de ensino no país e "disponibilizando" suporte a esses universitários, é uma questão que será discutida no segundo capítulo. No capítulo seguinte, analisaremos as dificuldades encontradas com a utilização do transporte coletivo que é um instrumento essencial para a maioria da população brasiliense, especificamente os universitários da UnB e os diversos problemas encontrados na malha viária local. No capítulo IV, faremos um breve histórico do surgimento e o crescimento da universidade e sua necessidade educacional no mundo. Por fim no capítulo V, serão discorridas, as análises obtidas nas entrevistas com os estudantes da UnB, dos diversos cursos, buscando através dos 
seus depoimentos, as respostas, para diante de tantas dificuldades prosseguirem com suas metas e objetivos. 


\section{CAPÍTULO 1}

\section{O surgimento e características da cidade de Brasília}

As cidades possuem algumas características próprias como diferentes dimensões e paisagens. Elas são centros de decisões e possuem diversos segmentos (comércio, indústria, trabalhadores, etc) com dinâmica própria. Esses fatores fazem com que cada cidade tenha suas características de crescimento, que podem ser avaliadas de maneiras diferentes.

O surgimento da capital nacional "Brasília" proporcionou a população brasileira, novas oportunidades de mudanças na vida social, tornando-a uma capital de migrantes, cidade nômade, uma cidade que surge no centro do Brasil e que se constitui em uma tentativa de mudança geográfica, social e ideológica. A transferência da capital é um fenômeno que tem ocorrido no país com relativa frequência. Do período do descobrimento do Brasil, até os momentos atuais, já houve três mudanças da capital brasileira. Salvador foi a primeira mudança, realizada no período colonial e em 1763 e foi substituída pelo Rio de Janeiro. Objetivando a ocupação do território e uma melhor defesa estratégica (militar), a capital brasileira foi transferida pela última vez para a nova cidade de Brasília que foi idealizada e construída em 1960, no então, governo de Juscelino Kubitschek, com uma peculiaridade de abrigar a sede do governo, tornando-se então, a "Capital Federal”. Essa simetria é importante para podemos entender como se processou a relação entre a cidade e seus moradores.

Richart Sennett ${ }^{5}$ utiliza dois conceitos que serão de fundamental importância para se entender à cidade como fenômeno a partir da relação entre uma cidade orgânica e uma cidade inorgânica. Os conceitos de urbs e civitas serão importantes como instrumentos teóricos para a compreensão dessa relação à cidade de concreto e a cidade de carne. $\mathrm{O}$ conceito urbs refere-se ao componente material da cidade ou a parte propriamente física, ou seja, edifícios, pontes, igrejas, hospitais, casas, ruas, aonde não são consideradas a extensão e a hierarquia entre esses elementos. O termo urbanização decorre da palavra urbs e indica o conjunto de atos que tendem a criar um agrupamento de construções e pretende regular o seu

\footnotetext{
5 SENNETT, Richard. Carne e Pedra: o corpo e a cidade na civilização ocidental. $2^{\text {a }}$ ed. Rio de Janeiro:
} Record, 2001. 
funcionamento. Os arquitetos e urbanistas trabalham com esses significados, para definir urbanização. Para os sociólogos, urbanização é um processo caracterizado pela transferência de pessoas da área rural para as cidades e os geógrafos definem como intimamente associados à concentração de muitas pessoas em um espaço restrito (a cidade) e na substituição das atividades primárias (agropecuária) por atividades secundárias (indústrias) e terciárias (serviços).

Entretanto, por se tratar de um processo, costuma-se conceituar urbanização como sendo "o aumento da população urbana em relação à rural", e nesse sentido só ocorre urbanização quando o percentual de aumento da população urbana é superior a da população rural.

É quando ocorre um crescimento das cidades em vista dessa migração de grupos provenientes da área rural. Utilizaremos urbanização no sentido geográfico ampliando seu significado e procurando uma definição que se relacione diretamente com a forma urbana de uma cidade.

O conceito civitas refere-se à vida social, política e imaginária dos habitantes da cidade. A palavra civitas é apropriada para designar os habitantes da urbs, parte material da cidade, que são os cidadãos, e é de onde deriva a noção de cidadania. Quando uma capital é transferida de uma cidade para outra, ela deixa para trás a sua urbs, a parte material, mas traz consigo aspectos fundamentais, da civitas. No caso de Brasília, a civitas será configurada pelos diferentes imigrantes que se transferiram para a cidade desde a época de sua inauguração até os dias atuais. Os conceitos de urbs e civitas são importantes para reconstruir Brasília a partir da cidade e de seus habitantes, ou seja, abordagem da cidade deve ser realizada tanto a partir de sua base material, concreta, quanto de sua parte orgânica, humana. As compreensões de como estes elementos estão combinados e de que forma são apresentados na atual forma da cidade nos permite compreender em que medida a cidade corresponde a uma subjetividade coletiva e de que forma os moradores se relacionam com a cidade. A cidade moderna abriga um homem do mundo desencantado e que se encontra perdido entre uma nova concepção de espaço e de tempo.

Brasília é uma cidade moderna e, nesse sentido, deve ser compreendida em seu tempo. Simmel ${ }^{6}$ é um dos primeiros pensadores a se dedicar ao estudo da cidade moderna e

6 SOUZA, Jessé e OELZE, Berthold (org); Simmel e a Modernidade. Brasília: Editora Universidade de Brasília, 1998. 
das suas influências sobre os indivíduos. O principal objeto da análise de Simmel é a relação do indivíduo com aquilo que é supra-individual, ou seja, o conflito entre o individuo e a sociedade. Para Simmel, o dinheiro atua com um nivelador entre os indivíduos modernos. O dinheiro transforma as relações pessoais em impessoais possibilitando uma objetividade entre os indivíduos, que passa ser constitutiva da cidade moderna.

As grandes cidades são os produtos da economia monetária por excelência. $\mathrm{O}$ dinheiro confere às grandes cidades suas duas características mais marcantes: De um lado, o intelectualismo e a calculabilidade, e do outro a indiferença. Os indivíduos da cidade dão uma ênfase grande aos relacionamentos sociais intelectualizados em oposição às relações baseadas no sentimento e na pessoalidade típicas das pequenas cidades e das comunidades rurais. Esse tipo de comportamento é determinado pela necessidade de estabelecer medidas objetivas para comparar desempenhos, produzir previsibilidades, exatidão e competição impregnam a existência do morador da grande cidade de tal forma que lhe confere um ritmo próprio, nervoso, ansioso, repressivo com relação aos seus instintos e necessidades. $\mathrm{O}$ indivíduo metropolitano é indiferente e intelectualizado, como insiste Simmel.

Com o crescimento inesperado das cidades-satélites, a população do DF aumentava a uma taxa considerada a maior do país, devido principalmente à migração interna. Brasília também era conhecida por oferecer, em fins da década de 1970, muitos empregos na área de construção civil. Na época era a maior fonte de empregos do Centro-Oeste. Brasília acabou cercada por cidades-satélites que, no plano original elaborado por Lúcio Costa, só deveriam começar a surgir por volta de 1990.

$\mathrm{Na}$ construção de Brasília não houve a preocupação ou visualização com a possibilidade do crescimento populacional, em consequiência disso, está acontecendo um aumento excessivo da população, que também faz parte dos problemas de difíceis resoluções e que não podem ser resolvidos com desfechos imediatistas e de curto prazo. Além de algumas mudanças no projeto original, que alteraram o desenho urbano, houve uma negligência por parte dos governos quanto aos problemas que poderiam surgir da distribuição de lotes e, consequentemente, o surgimento de novas cidades, sem nenhum estudo prévio para fins eleitorais, a imigração proporcionada por esta distribuição, a falta de um transporte público eficiente e de qualidade, que conduzirá esse cidadão aos diversos lugares da cidade, inclusive a UnB. 
A construção de Brasília absorveu pessoas de várias regiões do país. Eram os pioneiros, em busca de melhores condições de vida, deslumbrados pela possibilidade de trabalho e atraídos pela proposta de uma remuneração melhor. Eles viveram na chamada "Cidade Livre", hoje Núcleo Bandeirante e também na Vila Planalto. Muitas construções diversas delas em madeira, são conservadas até hoje e fazem parte do patrimônio histórico da cidade. Assim, a cidade recebeu sotaques, culturas e costumes de indivíduos que vinham de todas as regiões do Brasil, mobilizadas rapidamente para a execução deste grandioso empreendimento histórico.

A população da cidade é predominantemente jovem. Talvez por suas diferenças culturais e diversidades de costumes, esses jovens não incorporaram à sua pronúncia qualquer dos sotaques regionais trazidos de tantos locais, já que, com a imigração surgiram os filhos da terra, os brasilienses. Às festas, aos costumes, ao folclore, à cultura, certamente devem permanecer enraizados os regionalismos mais fortemente ensaiados aqui pelas correntes migratórias vindas de todos os pontos cardeais. O tempo e essa gente vêm definindo o que fica e o que sai de lá. Esses jovens vão, progressivamente, marcando a identidade cultural da cidade.

\section{Aspectos de expansão do aglomerado de Brasília}

Em termos gerais, o Aglomerado Urbano apresenta uma dupla realidade: a de fronteira econômica e de centro urbano consolidado. Dentre as características de fronteira econômica, o Aglomerado Urbano, ainda continua a representar a imagem de "Eldorado do cerrado", para onde se dirige boa parte do fluxo migratório regional, além de apresentar elevadas taxas de mudança de uso de solo rural para urbano e incorporação de terras ao setor produtivo. Com relação às semelhanças com os centros consolidados, o Aglomerado Urbano apresenta características e problemas de porte metropolitano com é o caso das elevadas taxas de urbanização, do arrefecimento das taxas de crescimento demográfico nas áreas centrais e da ampliação do grau de integração funcional e espacial entre os municípios goianos mais próximos ao Distrito Federal, além dos crescentes índices de violência urbana. Compartilha também com as demais metrópoles brasileiras problemas relativos à difusão da pobreza em 
todo o território, a crescente 'mercantilização' de terras em áreas periféricas para populações de média a alta renda e a piora dos indicadores de moradia e saneamento básico adequado.

No que se refere aos movimentos populacionais, a partir da década de 70, o DF registrou uma emigração de 6.650 pessoas para o estado de Goiás, passando nas décadas seguintes para 15.634 pessoas ao ano, consolidando Luziânia, Planaltina e Santo Antonio do Descoberto como o principal espaço de concentração de emigração, receptáculo das demandas por moradia não atendida no DF. Entre 1995 e 2000, o DF exportou 80.550 pessoas para os municípios goianos, dos quais $42 \%$ passaram a residir em Águas Lindas de Goiás. Esse quadro é representativo da tendência de reforço da desconcentração demográfica no DF, movimento inverso ao observado no período de construção da nova capital federal. Com isso, pode-se afirmar que o atual padrão de urbanização do Aglomerado Urbano de Brasília não parece estar associado a migrações inter-regionais. O padrão de urbanização mais recente parece estar ligado à intensificação das migrações intrametropolitanas, à mobilidade pendular e à crescente ocupação de áreas rurais para fins urbanos. ${ }^{7}$

7 Segregação e reprodução das desigualdades sócio espaciais no Aglomerado Urbano de Brasília - VII Seminário Internacional da LARES 25 - 26 de outubro de 2007, São Paulo, Brasil George Alex Da Guia, Lúcia Cony Faria Cidade. Disponível em: $\langle$ http://biblioteca.universia.net/ficha.do?id=6357473 $>$. Acesso em 20 abr 09. 


\section{CAPÍtUlo II}

\section{História da Universidade de Brasília}

Brasília tinha apenas dois anos quando ganhou oficialmente sua universidade federal. Inaugurada em abril de 1962, a Universidade de Brasília (UnB), já funcionava desde o início do mês, nas dependências do Ministério da Saúde, na Esplanada dos Ministérios. Em 09 de abril começou as aulas para os 413 alunos que haviam prestado o primeiro vestibular na instituição que viria a se tornar uma das mais bem conceituadas do Brasil.

Trilhar esse caminho, no entanto, demandou esforços. A princípio até para convencer as autoridades da importância de uma universidade da capital. Ainda que o projeto original de Brasília, feito pelo arquiteto Oscar Niemeyer e pelo urbanista Lúcio Costa, já previsse um espaço para a UnB - entre a Asa Norte e o Lago Paranoá -, a luta pela construção foi grande. Tudo por causa da proximidade com o Palácio do Planalto, o Congresso Nacional e a própria Esplanada dos Ministérios. Algumas autoridades não queriam que estudantes interferissem na vida política da cidade. Finalmente, depois de negociações intensas, em 15 de dezembro de 1961, o então presidente da República João Goulart sancionou a lei 3.998, que autorizou a criação da universidade.

O antropólogo Darcy Ribeiro, idealizador, fundador e primeiro reitor da UnB, sonhava com uma instituição voltada para as transformações - diferentes do modelo tradicional criado na década de 1930. No Brasil, foi a primeira a ser dividida em institutos centrais e faculdades. É, nessa perspectiva, foram criados os cursos-tronco, nos quais os alunos tinham a formação básica e, depois de dois anos, seguiam para os institutos e faculdades. Os três primeiros curso-troncos eram: Direito, Administração e Economia, Letras Brasileiras, e Arquitetura e Urbanismo.

A inauguração da UnB assemelhou-se em muito à própria capital, quase tudo era canteiro de obras, pouquíssimos prédios estavam prontos. O Auditório Dois Candangos, onde 
ocorreu à cerimônia, havia sido finalizado vinte minutos antes. Seu nome homenageia os pedreiros Expedito Xavier Gomes e Gedelmar Marque, que faleceram soterrados em um acidente durante a construção.

A instituição tinha então treze mil metros quadrados de área construída, distribuídos em nove prédios, trinta e cinco vezes menor do que em 2006 (quatrocentos e sessenta e quatro mil metros quadrados), segundo a Secretaria de Planejamento da UnB. No início, somente os estudantes de Arquitetura e Urbanismo assistiam às aulas no campus em obras, para que pudessem praticar. Os outros cursos eram ministrados no $9^{\circ}$ andar do Ministério da Saúde. A administração e a reitoria ocupavam parte do Ministério da Educação.

Com o passar dos anos o crescimento da universidade e o desenvolvimento ocorrido nos Centros Acadêmicos, mudou radicalmente a estrutura da universidade. O Compromisso social da universidade também aumentou em outras frentes. A começar pela expansão do próprio número de alunos matriculados. Segundo a Secretaria de Planejamento SPL, em 2002, a UnB tinha 21.734 alunos regulares registrados nos cursos de graduação, 32\% a mais que 1998 e quase 53 vezes o número de alunos do primeiro vestibular em 1961. Atualmente, possui mais de 1.400 professores e cerca de 2.230 servidores. A UnB oferece 72 cursos de graduação, 64 de mestrado, 45 de doutorado e dezenas de especializações. Os órgãos complementares auxiliam os alunos no desenvolvimento de trabalhos de ensino, pesquisa e extensão. São eles: o Hospital Universitário de Brasília, a Biblioteca Central, a Fazenda Água Limpa, o Centro de Informática, a UnB TV e a Editora UnB e os novos campi universitários.

A Universidade de Brasília tem uma área total de $3.960 .579 \mathrm{~m}^{2}$, e uma área construída de $470.289 \mathrm{~m}^{2}$, que dificulta o deslocamento interno e externo dos seus funcionários, professores e alunos, já que a quantidade e qualidade dos ônibus oferecida é precária, só acontecendo com maior fluxo nos horários de pico que são das 07h00min às 08h00min e $12 \mathrm{~h} 30 \mathrm{~min}$ às $18 \mathrm{~h} 00 \mathrm{~min}$. Com o objetivo de facilitar o deslocamento, no período noturno de alunos, professores e funcionários da UnB para suas residências, é ofertado gratuitamente um ônibus que circula perto do campus, circulando em uma e uma hora, saindo 
do Centro Olímpico $(\mathrm{CO})$ da UnB às $18 \mathrm{~h} 45 \mathrm{~min}$ e o último horário circulando das $23 \mathrm{~h} 45 \mathrm{~min}$, saindo da Biblioteca Centra da UnB (BCE) com destino a L2 Norte. ${ }^{8}$

É fato que o corpo acadêmico e todos os outros funcionários, frequentadores assíduos do campus universitário sentem a necessidade de mais transporte com qualidade e, que beneficie a mobilidade pendular, estimulando e incentivando todos aqueles que necessitam de transporte coletivo. 


\section{CAPÍTULO III}

\section{Transporte coletivo}

O transporte de pessoas numa cidade, atualmente, é de vital importância para o desenvolvimento das mais diferentes atividades, sejam elas produtivas, sejam elas de apoio. Quando consideramos apenas as pessoas, elas estão circulando, se deslocando de casa ao trabalho, a escola ou para o lazer. Sobre as metrópoles, onde a aglomeração de veículos nas ruas provoca um deslocamento lento, podemos dizer que as pessoas às vezes têm mais trabalho para circular quando, na realidade, deveriam circular com facilidade para trabalhar, diminuindo o desgaste do tempo útil de cada um.

Um dos maiores desafios para as administrações de cidades médias (aquelas que já atingiram 200.000 habitantes) e de metrópoles é o do transporte coletivo urbano. Esse tipo de serviço deve ser entendido e aceito como um serviço público, seja ele explorado por uma empresa estatal, seja por uma empresa privada, cujo objetivo primeiro, no capitalismo, é a obtenção de lucro. Papel importante, neste caso, deve exercer o poder público, ao qual cabe a responsabilidade na organização do sistema e fiscalização de seu funcionamento, para garantir sua qualidade e a confiabilidade dos usuários. Por exemplo: os preços das passagens devem ser compatíveis com o poder de compra dos usuários; os horários dos ônibus devem ser cumpridos, para que possam chegar ao trabalho ou à escola na hora devida; os ônibus não devem circular com número exagerado de passageiros, isso gera desconforto e irritação e psicologicamente desmotiva esse transeunte.

A malha viária local vem passando por uma recuperação e construção de novas pistas com o intuito de agilizar o deslocamento populacional. Quando da elaboração da malha viária, houveram quatro falhas que prejudicam a interligação entre Brasília e dezenove regiões administrativas - do total de 30 existentes - em um verdadeiro labirinto. Primeiro pela distância entre os núcleos urbanos.

Os imensos espaços vazios entre eles agravam o problema. A falta de planejamento no desenho da malha viária e as poucas rotas de ligação entre uma cidade e outra completam a engrenagem que dificulta a vida dos moradores (Correio Brasiliense, Jun 
09), e, além disso, temos ônibus em mal estado de conservação, quebrando constantemente, não respeitando os horários estipulados e ocasionando atrasos, consequentemente, provocando desconforto aos que o utilizam, já que permanecem sempre cheios nos horários de pico, oferecendo insegurança, principalmente quando estão em alta velocidade, justamente para compensarem o tempo perdido nos engarrafamentos.

O sistema de transporte afeta, a todos, que vivem na cidade e deve ser encarado como um sistema dinâmico, em constante aperfeiçoamento, suas modificações devem sempre levar em consideração a opinião de todos os interessados e especificamente neste trabalho, os alunos entrevistados, que colaboraram com suas opiniões enfrentando diariamente, várias adversidades.

Assim, como elemento importante, na estruturação da cidade, o transporte coletivo deve ser objeto de constantes transformações. Por exemplo:

1) a densidade (número de ônibus) deve ser compatível com a largura das vias de circulação, principalmente nos "horários de pico", geralmente pela manhã e pela tarde, quando as pessoas de deslocam para o trabalho e universidades ou quando voltam para casa;

2) Para que os usuários não se cansem ou percam tempo nos deslocamentos, os itinerários devem ser os mais curtos possíveis, a malha viária de Brasília não prestigia essa mobilidade dificultando em muito a ligação interna entre as regiões administrativas;

3) As informações do sistema (itinerários, horários) devem sempre aparecer de forma simples e clara, para que todos, inclusive aqueles com menos escolaridade, possam entendê-las;

4) Os pontos dos ônibus devem ser cobertos, e em Brasília devido ao seu período de chuvas e verão intenso, essas necessidades ainda não foram suficientemente cumpridas;

5) A utilização do metrô minimiza e privilegia algumas RAs, como Águas Claras, Taguatinga, Samambaia, etc, porém não beneficia a todos os moradores destas localidades e principalmente não alcança boa parte das outras regiões administrativas, dificultando mais ainda esse deslocamento. O "metrô" torna-se uma opção viável, prática, de interesse da população, dando mais uma oportunidade àqueles que podem utilizá-lo regularmente e proporcionando aos que usam veículos particulares a oportunidade de utilizar menos os seus carros.

Santos, Milton (1978, p. 66 apud Baudrillard, 1973, p. 62): “que afirma que o automóvel é um dos mais importantes signos de nosso tempo e seu papel na produção do 
imaginário tem profunda repercussão sobre o conjunto da vida do homem, incluindo a redefinição da sociedade e do espaço. As cidades não seriam hoje o que elas são se o automóvel não existisse. Os homens acabam considerando o automóvel como indispensável e esse dado psicológico tornam-se um dado da realidade vivida. Ilusão ou certeza, o automóvel fortalece no seu possuidor a idéia de liberdade do movimento, dando-lhe o sentimento de ganhar tempo, de não perder um minuto, neste século da velocidade e da pressa. Com o veículo individual, o homem se imagina mais plenamente realizado, assim respondendo às demandas de status e do narcisismo, característicos da era pós-moderna”.

Cabe ressaltar que o metrô, ainda é restrito no DF, precisando ser estendido para as diversas regiões administrativas da cidade, facilitando de forma positiva a carência do transporte em nosso habitat e facilitando o deslocamento da população brasiliense nas diversas classes e consequentemente oferece a população nobre do Distrito Federal à oportunidade de não utilizar seus veículos diariamente, evitando assim, o caos urbano dos engarrafamentos, poluição do ar e até sonora (na cidade por educação evita-se utilizar buzinas), atropelamentos, colisões, stress mental, presenciável no cotidiano da nossa cidade.

O transporte público é reduzido nas diversas regiões administrativas, dificultando em demasia o deslocamento, a qualidade desse transporte é precária com péssima manutenção e ainda temos o total descaso por aqueles que administram tais veículos, uma preocupação mais imediatista com os lucros. Sabemos que o prazo máximo de utilização de maneira adequada e com segurança é de sete anos e meio e após, inicia-se as reposições, porém é constatado que a frota da cidade está próxima de extrapolar esse prazo. Atualmente o GDF está comprando novos ônibus, sendo distribuídos para algumas RAs como Brazlândia, Riacho Fundo II e Varjão (Correio Brasiliense, Mar 09), tentando minimizar a defasagem de veículos que a população do Distrito Federal vivencia neste momento. Não são muitas as opções para quem deseja chegar ao Campus Universitário Darcy Ribeiro de ônibus. Apenas vinte e sete linhas passam pelo local e elas levam a catorze cidades do Distrito Federal. Mas os horários concentram-se entre 06h00min e 08h00min e próximo às $12 \mathrm{~h} 00 \mathrm{mim}$ e $18 \mathrm{~h} 00 \mathrm{~min}$. Quem precisa chegar ou sair da UnB à noite - é o caso de alunos, professores e funcionários dos cursos noturnos - encontrará dificuldades. Apenas três linhas circulam depois de 20h00min (110, 330 e 349), de acordo com (tabela A) e cinco nos finais de semana (110, 110.2, 257, 338 e 339), de acordo com (tabela B). Nesses dias e horários, a solução é optar por aquelas que 
levam à Rodoviária do Plano Piloto. Elas passam de 06h00min as 00h00min em intervalos que vão de 10 minutos a duas horas. As tarifas variam entre $\mathrm{R} \$ 2,00$ e $\mathrm{R} \$ 3,00$.

a) Linha circular após as 2000 horas

\begin{tabular}{|c|l|}
\hline Linha Ônibus & \multicolumn{1}{c|}{ Itinerário } \\
\hline 110 & Rodoviária Plano Piloto, UnB - circular \\
\hline 330 & QNQ QNR/ Ceilândia Sul e Norte/Asa Norte, UnB \\
\hline 349 & Taquatinga Norte, L 2 Norte e Sul/ UnB \\
\hline
\end{tabular}

Tabela "A" - Elaborada pelo autor em 28 de junho de 2009.

b) Linha circular nos finais de semana

\begin{tabular}{|c|l|}
\hline Linha Ônibus & \multicolumn{1}{c|}{ Itinerário } \\
\hline 110 & Rodoviária Plano Piloto, UnB - circular \\
\hline 110.2 & Rodoviária , UnB para Caesb - circular \\
\hline 257 & Santa Maria, L 2 Sul e Norte \\
\hline 338 & QNR - P 2 Norte, L 2 Sul e Norte, Estrutural, UnB \\
\hline 339 & Setor P Sul, L 2 Norte e Sul UnB \\
\hline
\end{tabular}

Tabela "B" - Elaborada pelo autor em 28 de junho de 2009.

É o mais importante e significativo dos serviços, transportando em média 14.470.623 passageiros/mês. Utiliza veículos do tipo convencional, alongado, padronizado e articulado, num total de 2.337 veículos, para a operacionalização da rede básica do serviço de transporte por ônibus no Distrito Federal. Fazem parte do serviço convencional as empresas: Viplan, Condor, Lotaxi, Satélite, São José, Viva Brasília, Rápido Brasília, Riacho Grande, Veneza e TCB. É composto atualmente de 799 linhas que segundo suas características próprias, são classificadas em:

\begin{tabular}{|l|l|}
\hline Tipo de Linha & - Metropolitana 1 (Ligação Curta): \\
\cline { 1 - 2 } Itinerário & - Cidade-Satélite / Plano Piloto \\
\hline
\end{tabular}




\begin{tabular}{|l|l|}
\hline Tipo de Linha & - Metropolitana 2 (Ligação Longa): \\
\cline { 1 - 2 } Itinerário & - Cidade-Satélite / Plano Piloto \\
\hline Tipo de Linha & - Metropolitana 3 (Ligação Intermediária): \\
\cline { 1 - 2 } Itinerário & - Cidade-Satélite / Cidade-Satélite; \\
\cline { 1 - 2 } Itinerário & - Cidade-Satélite / Plano Piloto \\
\cline { 1 - 2 } Tipo de Linha & - Urbana 1 (Circular Curta): \\
\cline { 1 - 2 } Itinerário & - Cidade-Satélite e Plano Piloto \\
\cline { 1 - 2 } Tipo de Linha & - Urbana 2 (Circular Longa): \\
\cline { 1 - 2 } Itinerário & - Cidade-Satélite e Plano Piloto \\
\hline Tipo de Linha & - Urbana 3 (Circular Interna): \\
\cline { 1 - 2 } Itinerário & - Cidade-Satélite \\
\hline
\end{tabular}

Tabela "C" - Pesquisada pelo autor em 11 de maio de 2009

Conforme o Decreto $\mathrm{n}^{\mathrm{o}} 26.503 / 05$, as tarifas do Serviço Convencional passaram a vigorar com os seguintes valores:

\begin{tabular}{|c|c|c|c|}
\hline Tipo de Linha & Passagem Integral & $\begin{array}{c}\text { *Passagem com Desconto } \\
\text { (Estudante) }\end{array}$ & Decreto $\mathbf{N}^{\circ}$ \\
\hline Metropolitana 1 & $\mathrm{R} \$ 2,00$ & $\mathrm{R} \$ 0,66$ & $26.501 / 05$ \\
\hline Metropolitana 2 & $\mathrm{R} \$ 3,00$ & $\mathrm{R} \$ 1,00$ & $26.501 / 05$ \\
\hline Metropolitana 3 & $\mathrm{R} \$ 2,50$ & $\mathrm{R} \$ 0,83$ & $28.087 / 07$ \\
\hline Urbana 1 & $\mathrm{R} \$ 1,50$ & $\mathrm{R} \$ 0,50$ & $26.501 / 05$ \\
\hline Urbana 2 & $\mathrm{R} \$ 2,00$ & $\mathrm{R} \$ 0,66$ & $26.501 / 05$ \\
\hline Urbana 3 & $\mathrm{R} \$ 1,50$ & $\mathrm{R} \$ 0,50$ & $30.012 / 09$ \\
\hline
\end{tabular}

Tabela "D" - Pesquisada pelo autor em 11 de maio de 2009

* A passagem com desconto refere-se ao abatimento concedido aos estudantes regularmente matriculados nas entidades de ensino do Distrito Federal.

Diante do exposto no capítulo, observa-se que na prática esse deslocamento é precário, obrigando a população local, incluindo o universo entrevistado, buscarem melhores rotas, tentando minimizar o desânimo, cansaço e a preocupação diária com a parte financeira e principalmente a perda de tempo, provavelmente desestimulando esse aluno que tem de direcionar seu deslocamento de forma a adaptar-se com as linhas de ônibus disponíveis que o conduzirá para o centro universitário. 


\section{CAPÍTULO IV}

\section{A universidade no mundo e o seu crescimento}

Alexandre, o Grande, ao introduzir os chamados museus, encerra a semente das chamadas universidades de hoje, sendo que uma referência mais próxima na História é o surgimento das próprias universidades "em consequência do grande desenvolvimento das escolas ligadas às abadias e catedrais", durante a Idade Média antiga.

O Império Romano do Ocidente, embora unido pela língua latina, ainda englobava um grande número de culturas diferentes que haviam sido assimiladas de uma maneira incompleta pela cultura romana. Debilitado pelas migrações e invasões de tribos bárbaras, pela desintegração política de Roma no século $\mathrm{V}$ e isolada do resto do mundo pela expansão do Islão no século VII, o Ocidente Europeu chegou a ser pouco mais que uma colcha de retalhos de populações rurais e povos seminômades. A instabilidade política e o definhar da vida urbana golpearam duramente a vida cultural do continente. A Igreja Católica, como única instituição que não se desintegrou nesse processo, manteve o que restou de força intelectual, especialmente através da vida monástica. O homem intruído desses primeiros séculos era quase sempre um clérigo para quem o estudo dos conhecimentos naturais era uma pequena parte da escolaridade.

No final do século VIII, houve uma primeira tentativa de reerguimento da cultura ocidental. Carlos Magno conseguira reunir grande parte da Europa sob seu domínio. Para unificar e fortalecer o seu império decidiu executar uma reforma na educação. O monge inglês Alcuíno elaborou um projeto de desenvolvimento escolar que buscou reviver o saber clássico estabelecendo os programas de estudo a partir das sete artes liberais: o trivium, ou ensino literário (gramática, retórica e dialética) e o quadrivium, ou ensino científico (aritmética, geometria, astronomia e música). A partir do ano 787, foram emanados decretos que recomendavam, em todo o império, a restauração de antigas escolas e a fundação de novas. Institucionalmente, essas novas escolas podiam ser monacais, sob a responsabilidade dos mosteiros; catedrais, junto à sede dos bispados; e palatinas, junto às cortes. 
Essas medidas teriam seus efeitos mais significativos apenas séculos mais tarde. O ensino da dialética (ou lógica) foi fazendo renascer o interesse pela indagação especulativa; dessa semente surgiria à filosofia cristã da Escolástica. Além disso, nos séculos XII e XIII muitas das escolas que haviam sido estruturadas por Carlos Magno, especialmente as escolas catedrais, ganharam a forma de Universidades. Por outro lado o crescimento dos núcleos urbanos e o enriquecimento da sociedade aumentaram a demanda por educação e propiciaram a implantação dessas primeiras universidades resultantes da aplicação do modelo das ligas ou corporações de ofício no campo da educação.

Por volta de 1150 são fundadas as primeiras universidades medievais - Bolonha (1088), Paris (1150) e Oxford (1167) - em 1500 já seriam mais de setenta. Esse foi efetivamente o ponto de partida para o modelo atual de universidade. Algumas dessas instituições recebiam da Igreja ou de Reis o título de Studium Generale; e eram considerados os locais de ensino mais prestigiados da Europa, seus acadêmicos eram encorajados a partilhar documentos e dar cursos em outros institutos por todo o continente.

Um marco fundamental foi a criação em 1747, da École Nationale dês Ponts et Chaussés, em Paris, que vem a ser a mais antiga Grande Escola da França. Em 1810, é criada, por Dom João, a Academia Real Militar, origem da Escola Politécnica do Rio de Janeiro. No início do século XIX, com a vinda da Missão Artística Francesa, instala-se no Rio de Janeiro, em 1826, a Academia de Belas Artes. Em 1875 funda-se a Escola de Minas de Ouro Preto, destinada a formar Engenheiros de Minas e Geólogos. Em 1911, concretiza-se o projeto definitivo da Escola. Em 1920 foi criada, pelo governo federal, a primeira universidade "brasileira", a do Rio de Janeiro, que reuniu as Escolas Politécnicas, de Medicina e de Direito. Depois de sete anos foi criada a Universidade de Minas Gerais e, em 1934, a Universidade de São Paulo. A universidade do Brasil ainda não completou um século de existência formal.

Em decorrência de estudos e pesquisas realizados sobre a história da universidade brasileira, suas origens, desenvolvimento e impasses vivenciados até a Reforma Universitária de 1968, poder-se-ia observar que há um longo caminho a percorrer. Não se pretende afirmar, com isso, que algumas conquistas já não se fizeram sentir. Neste sentido, a universidade é convocada a ser o palco de discussões sobre a sociedade, mas não em termos pluramente teóricos, abstratos. Deve ser o espaço em que se desenvolve um pensamento teórico-crítico de idéias, opiniões, posicionamento, como também o encaminhamento de propostas e alternativas para solução dos problemas. Não resta dúvida de que essas tarefas constituem um 
aprendizado difícil e por vezes exaustivo, mas necessário. A educação em Brasília no período de construção da cidade tinha como propósito se diferenciar da educação do restante do Brasil, sob os pressupostos do movimento Escola Nova, comandado pelo educador Anísio Teixeira e seguido, em especial, pelo antropólogo Darcy Ribeiro, o qual priorizava o desenvolvimento do intelecto em detrimento da memorização. A construção da Universidade de Brasília foi um marco e uma conquista dos seus idealizadores, diante das dificuldades impostas pela construção da capital federal e também da classe política da época, que visualizam a aproximidade da futura universidade ao Palácio do Planalto, o Congresso Nacional e a própria Esplanada dos Ministérios, uma oportunidade de possíveis realizações de manifestações e reivindicações. Mesmo com todos esses obstáculos a Universidade de Brasília seguiu adiante se tornando referência nacional. 


\section{CAPÍtulo V}

\section{Educação e oportunidade}

Essa pesquisa buscou através de entrevistas mostrar a situação atual dos alunos entrevistados. Envolvidos nesta busca empírica de respostas para entender como funciona a necessidade de através da educação, encontrar a fórmula para estabilidade financeira, preparando-se através da graduação e não esquecendo que o mercado exige especialização e qualificação que permitirá no mínimo estar em igualdade, ou melhor, preparado para enfrentar a competitividade que a sociedade exige.

O universo de alunos entrevistados tem o mérito de estarem matriculados numa das universidades públicas mais conceituadas do país. Através das entrevistas foi buscadas as respostas que possibilitam enfrentarem as diversas dificuldades para obtenção do grau superior. Utilizei amostras com vinte e cinco alunos dos diversos cursos (figura 1), Geografia, Filosofia, Letras, Ciências Contábeis, Histórias, Relações Internacionais, Matemática, Administração, Contabilidade e Pedagogia que tem a peculariedade de ser um curso noturno, que acaba tornando-se um complicador para diversos alunos que o frequentam, já que as aulas terminam tarde e há pouquíssima circulação de ônibus nesse turno, gerando preocupação com a violência e mais o cansaço adquirido depois de uma jornada de expediente, todos esses elementos dificultam em demasia a conclusão de um curso. 


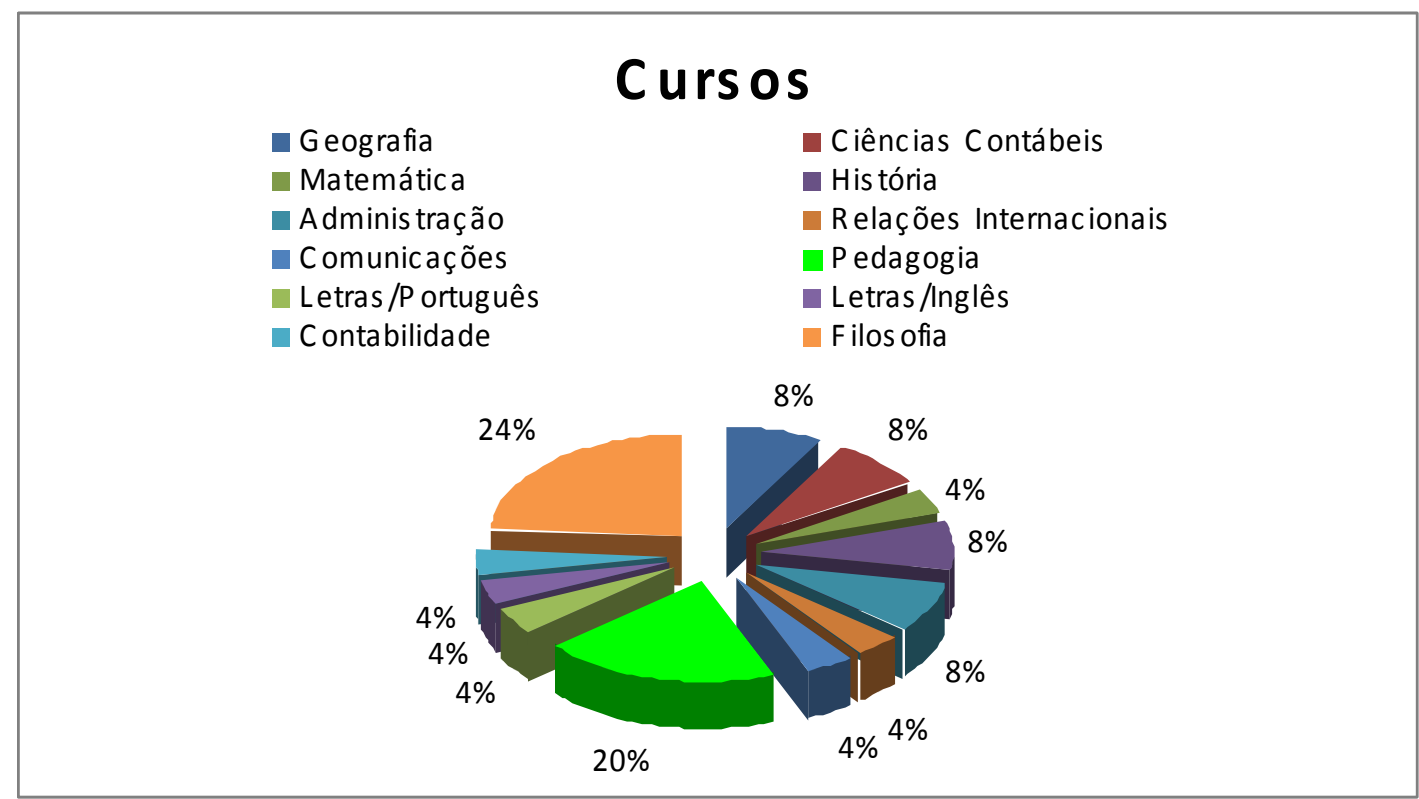

Figura 1 - elaborada pelo autor, em 15 de junho de 2009.

Foi observado a intinerância dos entrevistados que ocasiona a "migração pendular" que é caracterizada pela mobilidade do cidadão de uma região para outra, (figura 2), 60\% dos entrevistados são nascidos em outros estados confirmando essa mobilidade pendular inter-metropolitana e/ou inter-regional para o Centro-oeste (Brasília).

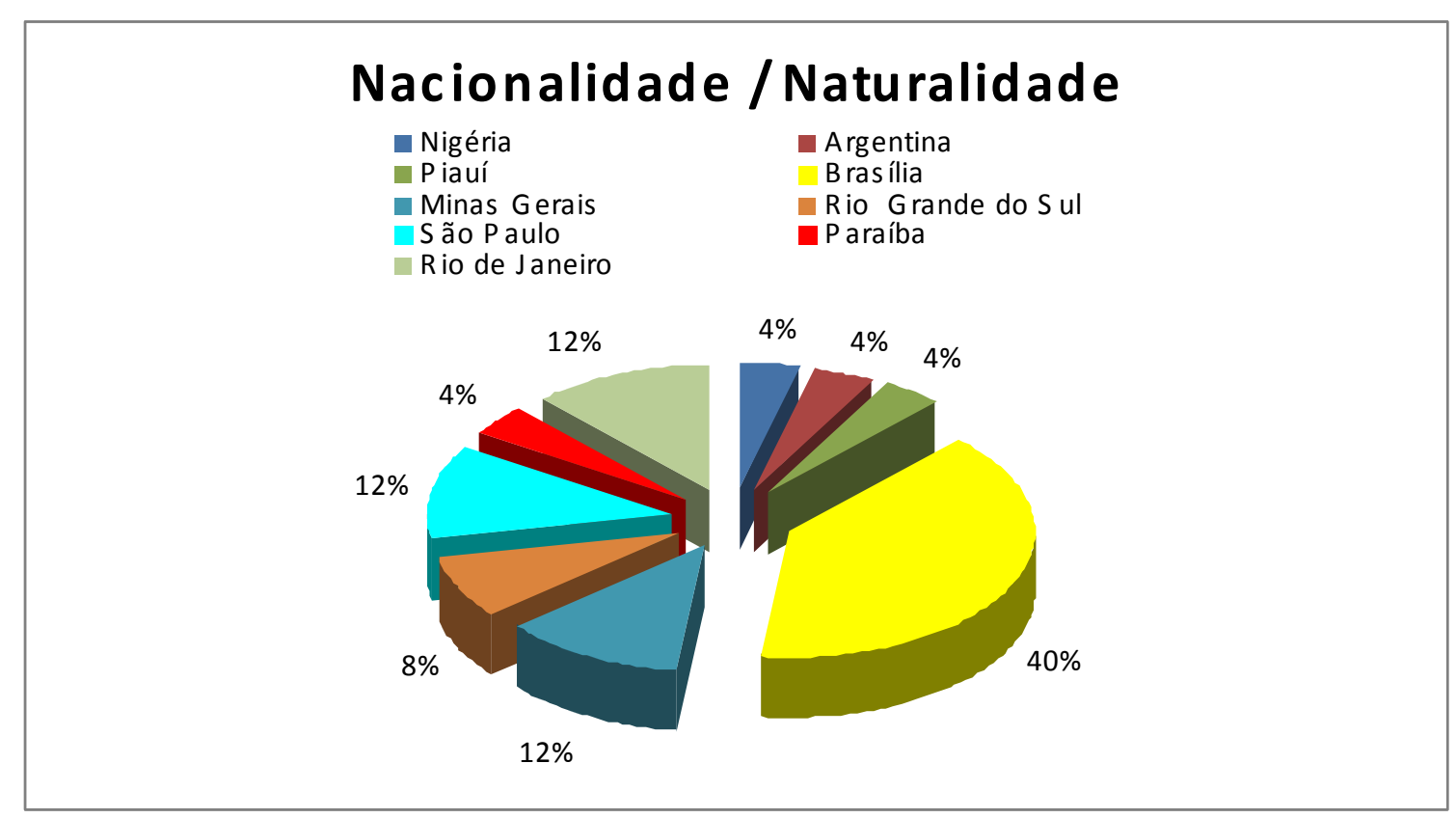

Figura 2 - elaborada pelo autor, em 15 de junho de 2009. 
As buscas por dados e informações foram conseguidas nos diversos pontos de ônibus da UnB, inclusive em horários diversificados. A faixa etária variou entre os alunos dos 17 a 41 anos de idade (figura 3), alunos na sua maioria, no início do curso, entre o $1^{\circ}$ e $4^{\circ}$ semestre, ainda bastantes motivados com suas conquistas e superando com bom humor as diversas dificuldades encontradas.

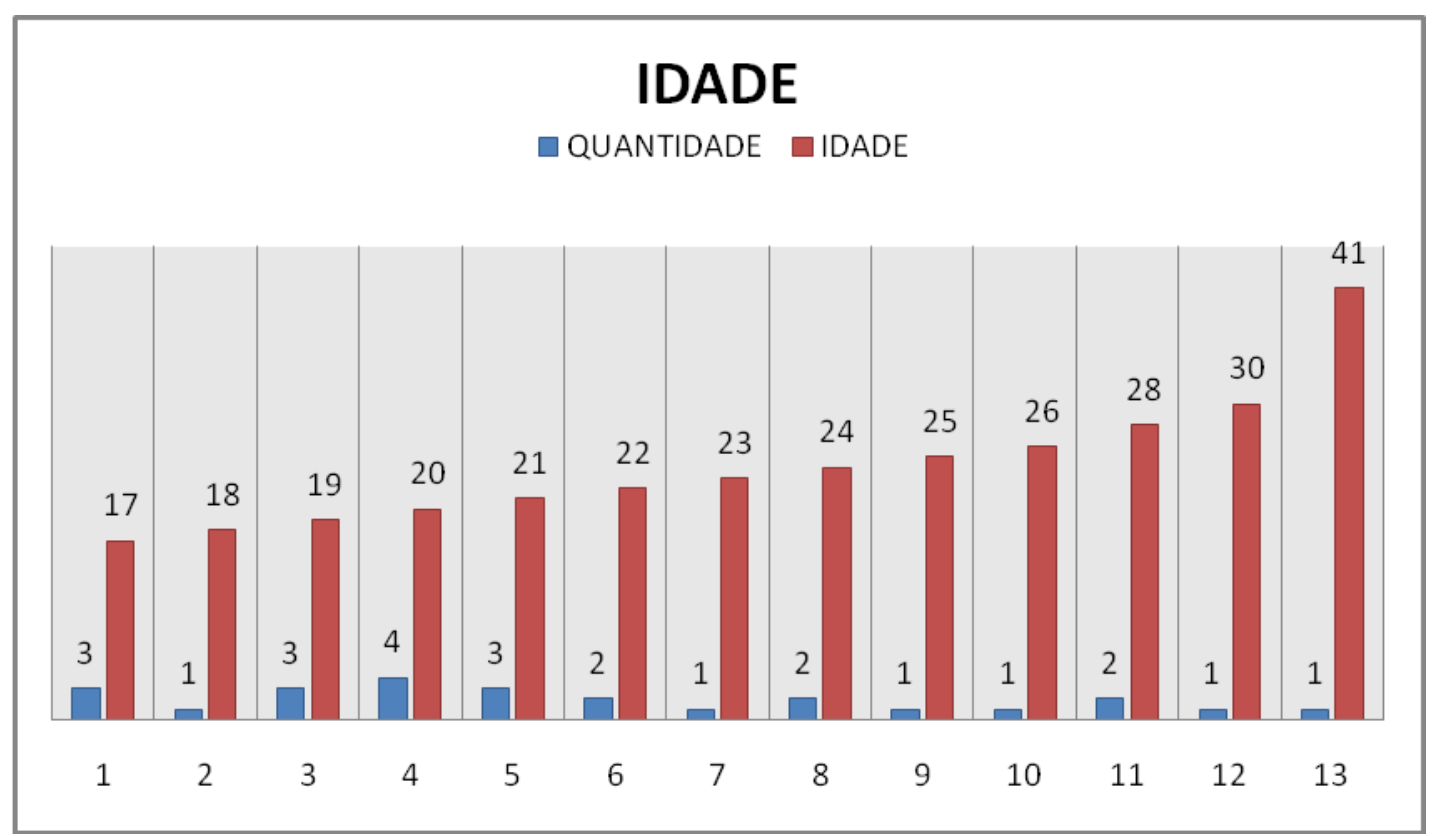

Figura 3 - elaborada pelo autor, em 15 de junho de 2009.

Diante da obtenção da aprovação para universidade pública, onde o primeiro obstáculo é a conquista do ensino gratuito, seguiremos adiante enfrentando, agora, a dificuldade da mobilidade no que se refere aos custeios de transporte para iniciar o curso e percebe-se que a maioria dos universitários, são jovens que necessitam do investimento de seus pais que financiam esse deslocamento. A importância do passe escolar torna-se essencial diminuindo consideravelmente esse débito. O passe escolar passa a ser de vital importância, diminuindo em demasia os custos daqueles que o utilizam, porém de acordo com alguns entrevistados ao utilizarem o cartão de passe, no leitor, muitas das vezes acontece de ser cobrada a tarifa integral desestruturando o orçamento elaborado e em contrapartida, para conseguir a devolução da quantia perdida, necessita-se de uma solicitação por escrito e um pouco de paciência.

Concomitantemente a esse problema os estudantes que trabalham ficam sobrecarregados, porque tem que conciliar seus horários de trabalho com os de estudos e não 
conseguindo esse acordo com os seus patrões, só poderão realizar cursos noturnos, com todas as implicações do deslocamento diário. A questão orçamentária necessita de um controle rigoroso, já que esse cidadão, a princípio, tem uma família para sustentar, para educar e proporcionar lazer, todos esses senões dificultam demasiadamente este contexto. Segundo alguns entrevistados, infelizmente alunos que conseguiram a tão sonhada aprovação e ingressaram na universidade, tiveram que trancar ou mesmo abandonar o curso, justamente por algumas imposições, característica da mobilidade pendular que estamos discutindo.

O deslocamento desses estudantes das regiões administrativas para UnB, de acordo com o resultado das entrevistas (figura 4), 72\% confirma que uma das maiores dificuldades é o tempo gasto aguardando o ônibus e somando também, a demora no deslocamento para o centro universitário, perde-se no mínimo 01h00mim e no máximo 02h00mim. Alguns alunos para alcançarem seu local de destino universidade/casa, ainda, têm que realizar caminhadas com longas distâncias e algumas noturnas, tendo, assim que superar mais um problema.

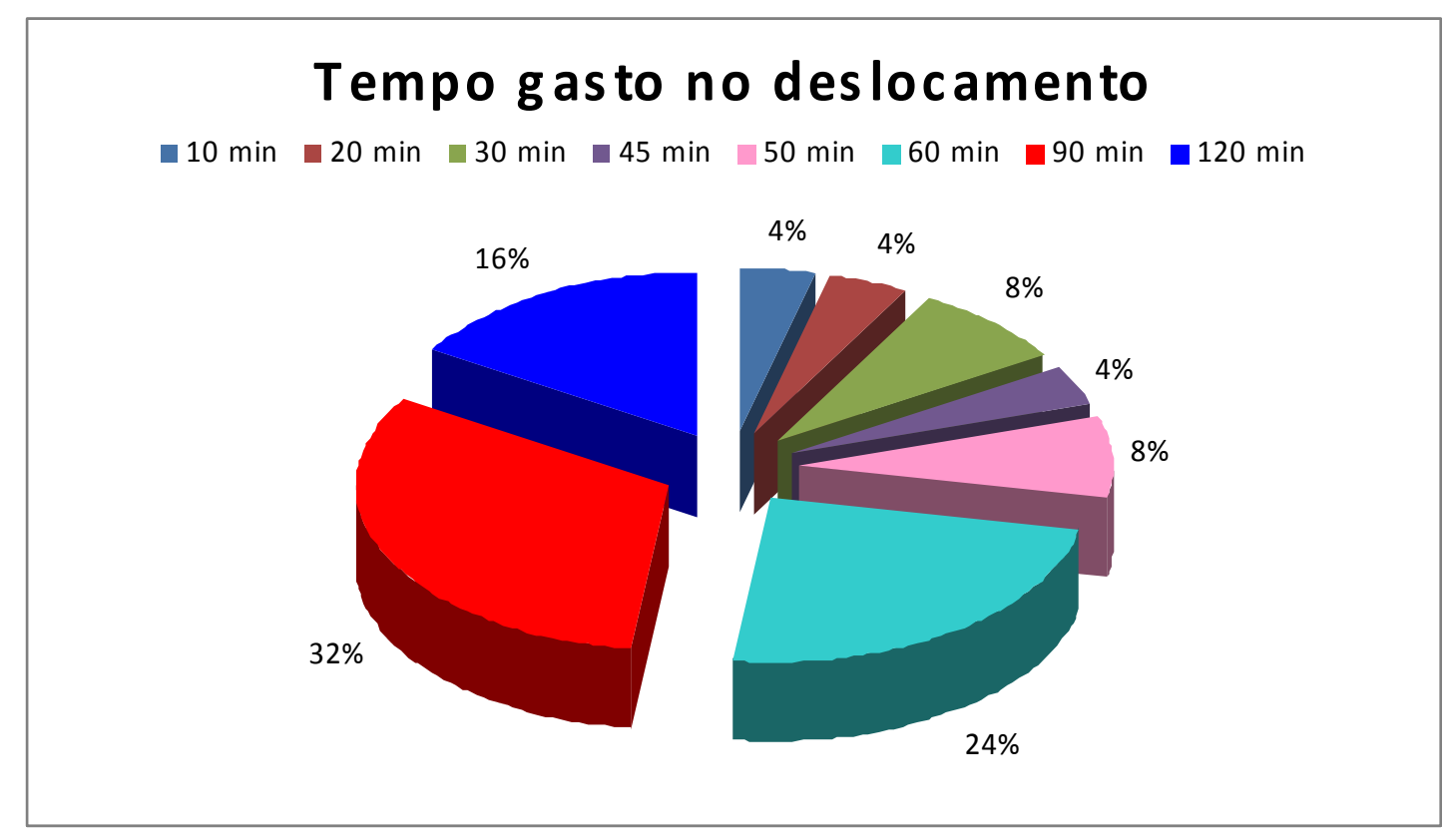

Figura 4 - elaborada pelo autor, em 15 de junho de 2009.

As maiorias das RAs citadas nas entrevistas geram um gasto de deslocamento de uma hora e trinta minutos a duas horas, utilizando dois ônibus, porém não é um resultado lógico. Um universitário que mora em Sobradinho, dependendo da localização da sua 
residência, poderá gastar o tempo enunciado nas linhas acima e/ou poderá gastar trinta minutos, utilizando apenas um ônibus. De acordo com as informações dos entrevistados, isso mostra as disparidades existentes dentro de uma região administrativas. Um exemplo mais próximo da UnB é o Lago Sul, onde uma universitária que gasta uma hora e trinta minutos e outra que gasta cinquenta minutos, ambas utilizam dois ônibus, isso consolida que não basta somente morar em determinada região, porém deverá estar muito bem localizada, na mesma, (figura 5).

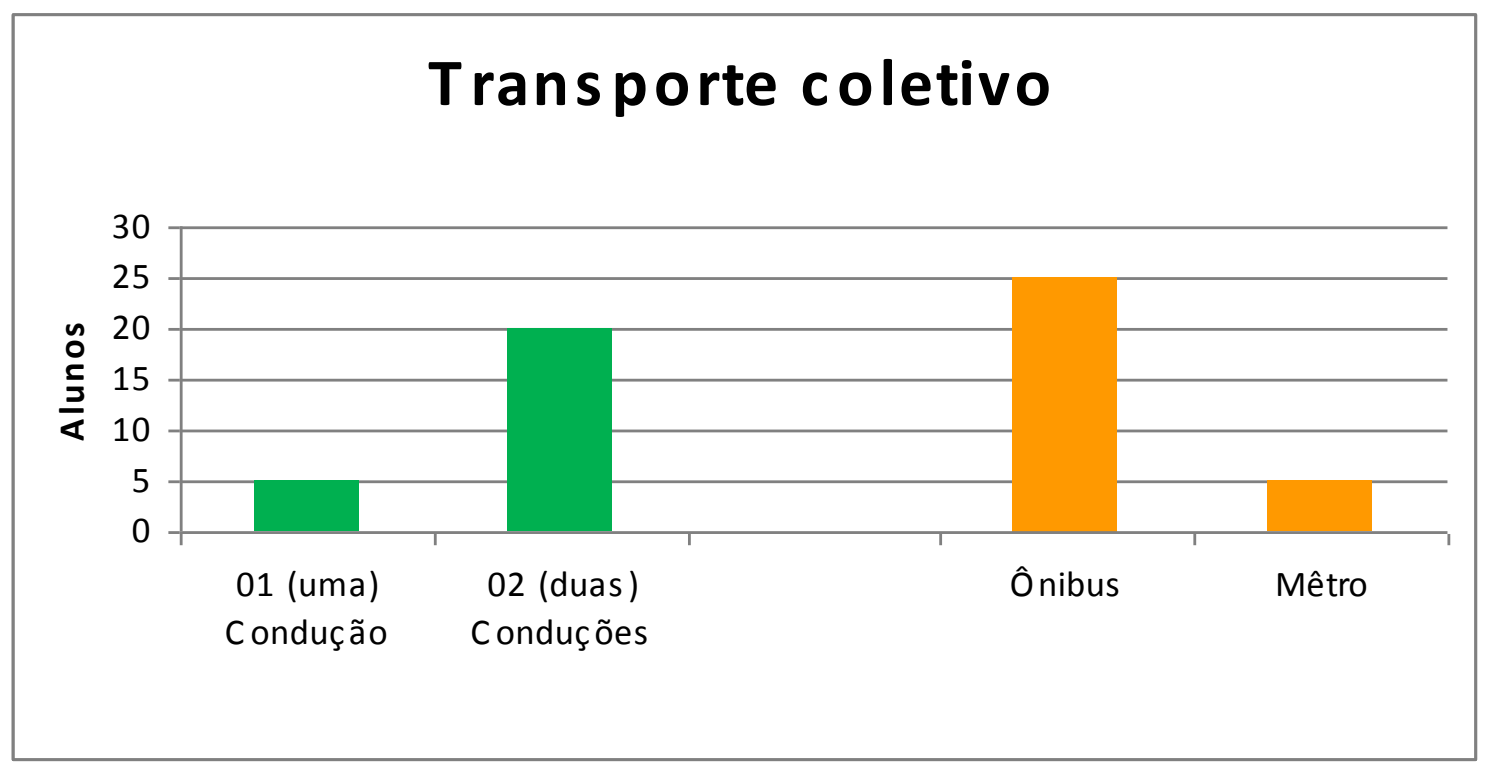

Figura 5 - elaborada pelo autor, em 15 de junho de 2009.

As cidades pertencentes ao estado de Goiás, não oferecem passe escolar encarecendo demasiadamente a utilização do ônibus por esse universitário, que mensalmente gastam aproximadamente 260,00 (duzentos e sessenta reais), mais que o triplo dos demais alunos que foram entrevistados (figura 6 e 7), dificultando em demasia o orçamento familiar de acordo com suas próprias informações. 


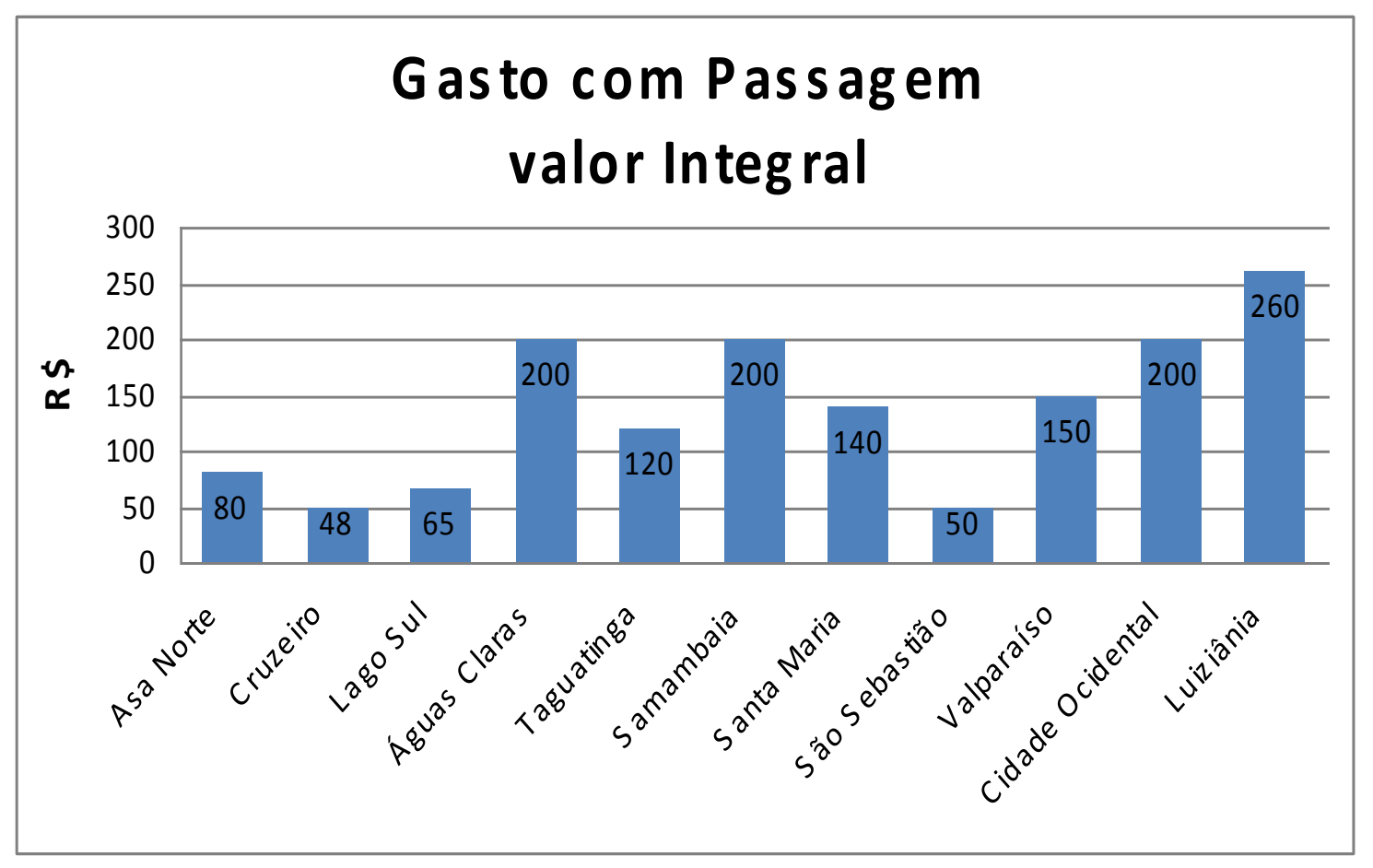

Figura 6 - elaborada pelo autor, em 15 de junho de 2009.

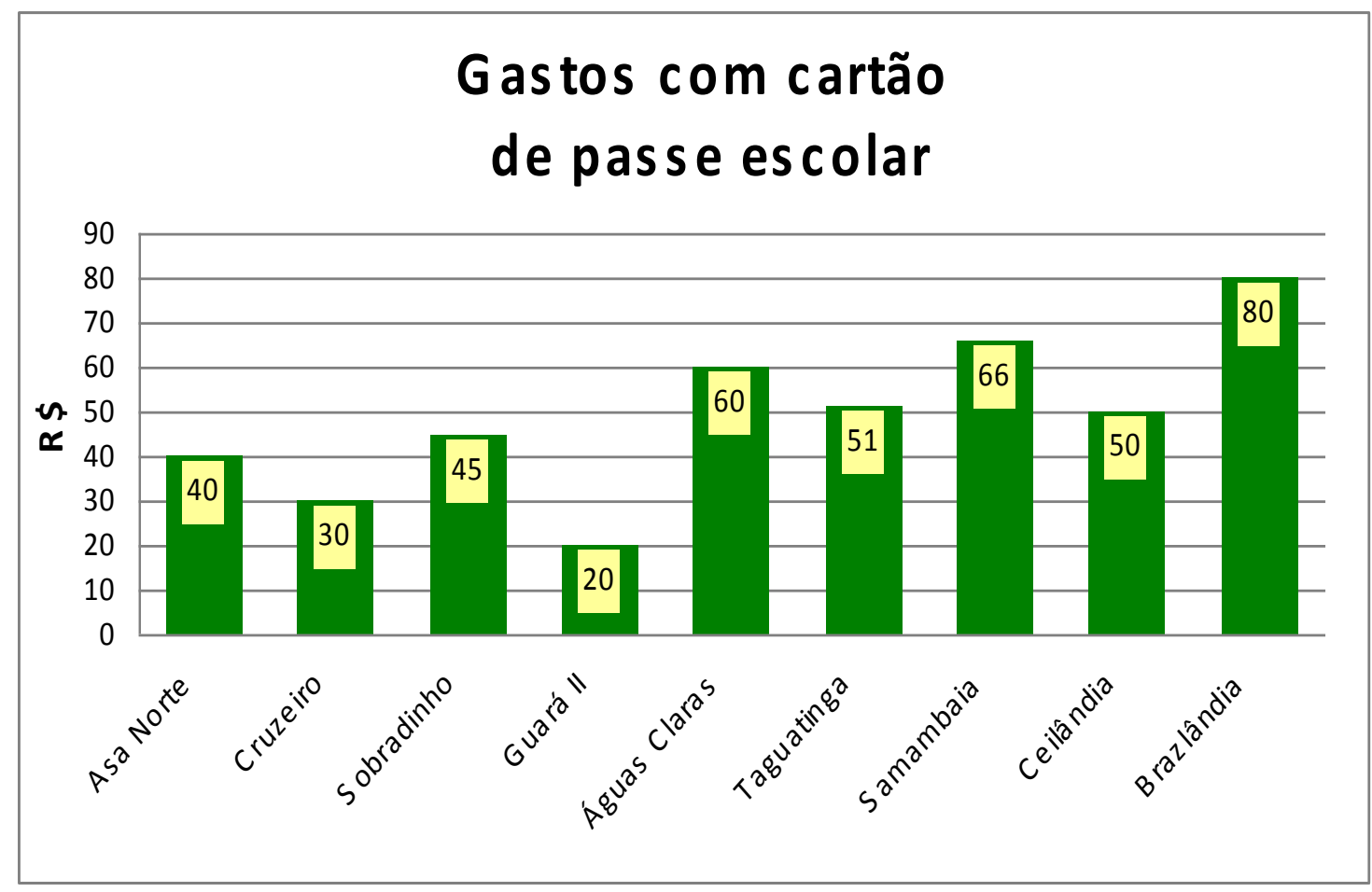

Figura 7 - elaborada pelo autor, em 15 de junho de 2009. 
Os motivos pêlos quais esses problemas persistem atualmente é a urbanização desordenada, o inchaço ocasionado pelas migrações inter-regionais e a necessidade do ser humano adquirir um automóvel para sua praticidade e conforto, tudo isso ocasionando a transformação do espaço e da paisagem da cidade. A necessidade de reformar e construir malhas viárias, por parte do GDF, com a boa intenção de evitar os engarrafamentos exagerados, a possível quebra do transporte pela má conservação das estradas, evitar acidentes e atrasos, situações que desestimulam e irritam qualquer cidadão em qualquer atividade.

O GDF, através dos seus representantes devem ter um comprometimento com sua população e mudar gradativamente a situação atual, ainda precária dos transportes coletivos. Há quase dez anos as entidades estudantis reivindicam a passagem gratuita e em consequiência dessas reivindicações foi votada pela Câmara Legislativa no mês de junho, a aprovação, com emendas, o projeto de lei 1.245/09 que para entrar em vigência, precisará da sanção do governado do DF. Entre as mudanças aprovadas que modificaram o projeto original, por exemplo, está a extensão do passe livre para alunos de todos os níveis, como alunos em estágios, de pós-graduação e de pré-vestibulares, como também a inclusão dos sistemas do metrô e de microônibus. Essas conquistas conduz, também, para excelência no transporte urbano local, da mesma forma que no Distrito Federal existe uma das melhores instituições educacionais do país.

Parece existir pouco comprometimento dos responsáveis em melhorar o quadro atual, as mudanças em detrimento da população acabam parecendo uma forma de manipulação e infelizmente, talvez, haja acomodação por aqueles que sentem na pele, esses transtornos diários. 


\section{CONSIDERAÇÕES FINAIS}

O presente trabalho analisou a mobilidade pendular enquanto fenômeno espacial e suas implicações no cotidiano do cidadão brasiliense, tendo como público alvo os universitários da UnB, estudantes esses que enfrentam as dificuldades vividas por cada trabalhador de nosso país, independente de classe social, obviamente aqueles que possuem mais recursos financeiros tem um deslocamento mais favorecido, enquanto conforto e uma utilização mais aproveitável do tempo, porém as dificuldades encontradas pela população são extremas diante do inchaço populacional, a imigração inter-regional ocasionando diversos problemas que incomodam a população local.

O Governo do Distrito Federal está recuperando, ampliando e construindo novas vias e com essa ação, recuperando a malha viária local. Também é interessante citar que um menor tempo em alguns semáforos, nas vias mais movimentadas da cidade, fará essa circulação ser mais ágil e flexibilizará esse movimento diário, realizado pelo povo brasiliense e os universitários da pesquisa.

O DFTrans deve utilizar sua fiscalização com mais rigor e coibir o manuseio de ônibus que estão sem condições de uso, evitando com essa atitude o desconforto e a perda de tempo pela população Brasiliense. A extensão da malha ferroviária é uma solução cabível ligando cada ponto da cidade e consequentemente proporcionará um melhor deslocamento, com um ganho considerável de tempo.

A Universidade de Brasília oferece mais três campi universitários: Planaltina, Ceilândia e Gama, proporcionando mais essa oportunidade para todos aqueles que buscam o aprimoramento intelectual, esses empreendimentos disponibilizam mais vagas e permitem a esses novos universitários a pretensa comodidade do deslocamento e um alívio financeiro para aqueles que moram mais próximo desses campi.

Uma reivindicação dos freqüentadores da UnB, que já é colocada em prática, é a utilização do ônibus gratuito em determinados horários noturnos, porém é sentido que a realidade é bem mais dolorosa, os responsáveis em administrar a universidade, devem oferecer mais transporte interno, oferecendo a esses cidadãos que permanecem até o último horário na universidade, agilidade em seus deslocamentos e proporcionando mais segurança. 
Cabe ressaltar que o metrô, ainda é restrito no DF, precisando ser estendido para as diversas regiões administrativas da cidade, facilitando de forma positiva a carência do transporte em nosso habitat e facilitando o deslocamento da população brasiliense nas diversas classes e consequentemente oferecendo a população nobre do Distrito Federal à oportunidade de não utilizar seus veículos diariamente, evitando assim, o caos urbano dos engarrafamentos, poluição do ar e até sonora (na cidade por educação evita-se utilizar buzinas), atropelamentos, colisões, stress mental, presenciável no cotidiano da nossa cidade.

A Câmara Legislativa votou o projeto de lei 1.245/09 - Lei do Passe Livre - que para entrar em vigor e beneficiar os estudantes de Brasília, aguardam ansiosos o Governador do Distrito Federal, sancioná-la.

O trabalho teve o propósito de expor as dificuldades encontradas pelos diversos alunos da UnB, e qual seria a melhor linha de conduta praticada pelo Governo do Distrito Federal, os responsáveis das empresas de ônibus e Administração da Universidade de Brasília, para viabilizarem respostas reais e concretas para resolução de diversos problemas que atingem diretamente os entrevistados e com certeza, boa parte dos universitários da instituição.

A classe acadêmica e todos que compõem, o campus universitário aguardam com expectativa mudanças que permitam uma melhor mobilidade pendular e, não somente para o publico referenciado, mais também a toda população de Brasília. 


\section{REFERÊNCIA BIBLIOGRÁFICA:}

ANTICO, Cláudia. Deslocamentos pendulares nos espaços Sub-regionais da Região Metropolitana de São Paulo. Trabalho apresentado no XIV Encontro Nacional de Estudos Populacionais, ABEP, realizado em Caxambu - MG - Brasil, de 20 a 24 set 04.

BERNADES, Adriana. Labirintos Urbanos. Correio Brasiliense, Brasília-DF, p 23, 13 jun 09.

CORRÊA, Roberto Lobato. O espaço urbano. São Paulo: Ed. Ática, 1986.

MATRAS, Judah. Outros métodos de pesquisa social. Coleção: Biblioteca Pioneira de Ciências Sociais. Ed. Livraria Pioneira: São Paulo, 1978.

SANTOS, Milton. A Natureza do Espaço: Técnica e Tempo, Razão e Emoção. - $4^{\mathrm{a}}$ ed. Editora Edusp, 2004.

SENNETT, Richard. Carne e Pedra: o corpo e a cidade na civilização ocidental. $2^{\mathrm{a}}$ ed. Rio de Janeiro: Record, 2001.

SPOSITO, Eliseu Savério. A Vida nas Cidades. Ed. Contexto: São Paulo, 2001.

RODRIGUES, Gizella. Mais ônibus nas ruas. Correio Brasiliense, Brasília-DF, p 36, 16 mai 09.

Brasília: Regiões Administrativas

<http://www.geocities.com/augusto_areal/regioes.htm>. Acesso em 28 jun 09.

Ciência medieval - Wikipédia, a enciclopédia livre, Disponível em:

<http://pt.wikipedia.org/wiki/Ciência_medieval>. Acesso em 22 abr 09. 
Estudo da concepção urbana de Brasília e a sua apropriação por parte da ... Emanuel Silva de Souza. Estudante do sexto semestre de Sociologia da UnB ... Disponível em: $\langle$ http://www.unb.br/ics/sol/itinerancias/bsb/urbanistico/concepcao.pdf $\rangle$. Acesso em $10 \mathrm{abr}$ 08 .

PEREIRA, Rafael Henrique Moraes. Polarização urbana e mobilidade espacial da população: o caso dos deslocamentos pendulares na rede pública do ensino médio do Distrito Federal. Disponível em: $<$ http://www.abep.nepo.unicamp.br/encontro2006/docspdf/ABEP2006_337.pdf $>$. Acesso em 18 abr 08.

PEREIRA, Rafael Henrique Moraes. Mobilidade Pendular: uma proposta teóricometodológica sobre o seu estudo.

Disponível em:

$<$ http://www.redaepa.org.ar/ixjornadas/resumenes/Se12Migraciones_Meichtry/mesa\%2012.../ MoraesPereira.pdf >. Acesso em 20 out 08.

PRESSUPOSTOS PARA A INTEGRACÃO ENGENHARIA/ARQUITETURA. Disponível em: $<$ http://www.sbpcnet.org.br/livro/58ra/SENIOR/RESUMOS/resumo_362.html $>$. Acesso em 21 abr 09.

SEGREGAÇÃO E REPRODUÇÃO DAS DESIGUALDADES SÓCIO ESPACIAIS NO AGLOMERADO URBANO DE BRASÍLIA - VII Seminário Internacional da LARES 25 26 de outubro de 2007, São Paulo, Brasil - George Alex Da Guia, Lúcia Cony Faria Cidade. Disponível em: $<$ http://biblioteca.universia.net/ficha.do?id=6357473 $>$. Acesso em 20 abr 09.

Transporte Urbano do Distrito Federal - DFTrans. Disponível em:

$<$ http://www.dftrans.df.gov.br/>. Acesso em 11 mai 09.

Universidade de Brasília. Disponível em:

<http://www.unb.br/sobre/principais_capitulos/criacao $>$. Acesso em 22 abr 09. 